\title{
Mineral Manganese Oxides as Oxidation Catalysts: Capabilities in the CO-PROX Reaction
}

\author{
Arantxa Davó-Quiñonero,* Sergio López-Rodríguez, Esther Bailón-García, Dolores Lozano-Castelló, \\ and Agustín Bueno-López
}

Cite This: ACS Sustainable Chem. Eng. 2021, 9, 6329-6336

Read Online

ABSTRACT: Cryptomelane is an abundant mineral manganese oxide with unique physicochemical features. This work investigates the real capabilities of cryptomelane as an oxidation catalyst. In particular, the preferential CO oxidation (CO-PROX), has been studied as a simple reaction model. When doped with copper, the cryptomelane-based material has revealed a great potential, displaying a comparable activity to the high-performance $\mathrm{CuO} / \mathrm{CeO}_{2}$. Despite stability concerns that compromise the primary catalyst reusability, $\mathrm{CuO} /$ cryptomelane is particularly

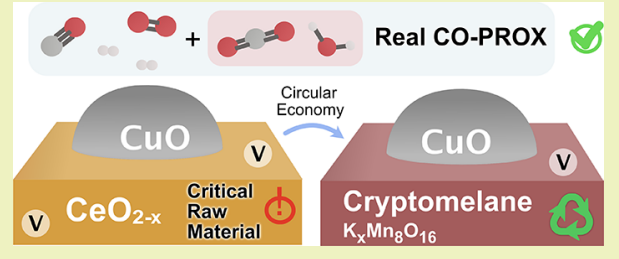
robust in the presence of $\mathrm{CO}_{2}$ and $\mathrm{H}_{2} \mathrm{O}$, typical components of realistic CO-PROX

streams. The CO-PROX reaction mechanism has been assessed by means of isotopic oxygen pulse experiments. Altogether, $\mathrm{CuO} /$ $\mathrm{CeO}_{2}$ shows a greater oxygen lability, which facilitates lattice oxygen enrolment in the CO-PROX mechanism. In the case of CuO/ cryptomelane, in spite of its lower oxygen mobility, the intrinsic structural water co-assists as active oxygen species involved in COPROX. Thus, the presence of moisture in the reaction stream turns out to be beneficial for the stability of the cryptomelane structure, besides aiding into the active oxygen restitution in the catalyst. Overall, this study proves that CuO/cryptomelane is a promising competitor to $\mathrm{CuO} / \mathrm{CeO}_{2}$ in $\mathrm{CO}-\mathrm{PROX}$ technology, whose implementation can bring the $\mathrm{CO}-\mathrm{PROX}$ technology and $\mathrm{H}_{2}$ purification processes a more sustainable nature.

KEYWORDS: rare earths, cryptomelane, cerium oxide, CO-PROX, reaction mechanism, isotopic oxygen, oxygen exchange

\section{INTRODUCTION}

Rare-earth elements (REE), with manifold uses in civil, industrial, and military sectors as permanent magnets or housing and electronic components, are considered critical raw materials since potential disruptions in their supply would put our technology developments at risk. ${ }^{1}$ Today, the REE market is rendered to a vulnerable chain supply by the dominance of China, which holds a powerful geostrategic position. ${ }^{2,3}$ Besides, REE manufacture relies on polluting practices with dramatic environmental impact. Regretably, REE recycling technologies are not commercially implementable yet and merely supply $1 \%$ of the market. ${ }^{4}$ Therefore, it is crucial to lower the REE demand by seeking functional substitute materials. This goal is a big scientific challenge owing to their unique magnetic, electrical, and optical properties, besides their well-recognized catalytic features. ${ }^{5}$

For instance, cerium oxides are renowned oxidation catalysts which have widely proven near-optimal catalytic performance several applications. ${ }^{6}$ Among reliable catalytic alternatives to cerium oxide materials, manganese oxides are promising candidates. In contrast to REE minerals, mineral manganese oxides are abundant and their extraction and beneficiation can be achieved by means of non-toxic, inexpensive, and environmentally-friendly procedures. ${ }^{7}$ In terms of catalytic activity, the mineral manganese oxide with the most promising catalytic properties is cryptomelane, which has attracted attention in the last years and centered some fundamental studies. ${ }^{8-10}$ The versatility of cryptomelane-based materials is due to their high porosity, acidity, hydrophobicity, electronic and ionic conductivities, and easy removal of lattice oxygen and recovery. These features are provided by the facile redox cycling among $\mathrm{Mn}^{2+}, \mathrm{Mn}^{3+}$, and $\mathrm{Mn}^{4+}$ states, leading to an average manganese valence of $c a$. 3.8. Chemically, cryptomelane is a potassium-manganese mixed oxide consisting in a tunneled structure formed by double chains of corner-sharing $\mathrm{MnO}_{6}$ octahedra basic units. The channel size left in between the $2 \times 2$ octahedra arrangement is $0.46 \times 0.46 \mathrm{~nm}$, and $\mathrm{K}$ ionic species and water molecules are hosted inside providing structural stability. The structure and composition of mineral cryptomelane can be achieved easily by inexpensive laboratory procedures leading to a synthetic material commonly named as octahedral molecular sieve $2 \times 2$ (OMS-2). ${ }^{11}$

In addition, it is well-known that the redox properties of cryptomelane can be tuned by means of the introduction of different framework dopants. ${ }^{12-14}$ In particular, the best

Received: January 16, 2021

Revised: April 1, 2021

Published: April 26, 2021

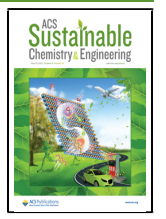


catalytic improvements have been achieved with $\mathrm{Cu}^{2+}$ doping, ${ }^{15,16}$ in an interesting analogy with the first $\mathrm{CO}$ oxidation hopcalite catalysts. ${ }^{17}$ On the other hand, the interfacial redox properties occurring by means of synergistic effects in $\mathrm{Cu}$-doped cryptomelane display similarities of the well-reported $\mathrm{CuO} / \mathrm{CeO}_{2}$ catalysts. ${ }^{18}$ As a result of them, although $\mathrm{Cu}$-modified cryptomelane materials are known to be more catalytically active systems than bare cryptomelane, $\mathrm{Cu}$ doping leads to a low thermal stability, which is a challenging limitation for their durable utilization in a hypothetic implemented use.

This work is aimed to provide a critical analysis of the feasibility of $\mathrm{Cu}$-doped cryptomelane in terms of activity and stability to study its potential implementation and substitution of cerium oxides. Herein, a straightforward comparison between $\mathrm{CuO} / \mathrm{CeO}_{2}$ and $\mathrm{CuO} /$ cryptomelane catalytic systems is presented for the preferential $\mathrm{CO}$ oxidation reaction $(\mathrm{CO}$ PROX) as the model case, which is relevant for the $\mathrm{H}_{2}$-rich stream purification. ${ }^{19}$ The catalytic performance and reusability under different gas mixtures has been tested, and the catalyst state after utilization has been carefully characterized. In addition, isotopic oxygen exchange experiments performed on the $\mathrm{CuO} / \mathrm{CeO}_{2}$ and $\mathrm{CuO} /$ cryptomelane systems have allowed to draw key mechanistic differences on the CO-PROX mechanism for the first time. In this study, the nature of the diverse active oxygen species existing in the ceria and the cryptomelane-based catalyst has been elucidated and their contributions in the $\mathrm{CO}$ oxidation mechanism evaluated. The results reveal promising opportunities for $\mathrm{CuO} /$ cryptomelane catalysts in the CO-PROX application, especially in the presence of moisture, because $\mathrm{H}_{2} \mathrm{O}$ aids the regeneration of labile oxygen species in the cryptomelane structure. Thus, the implementation of cryptomelane-based catalysts is proven to be an efficient and more sustainable approach into the exhaustive catalytic $\mathrm{CO}$ clean-up required for $\mathrm{H}_{2}$ safe use.

\section{EXPERIMENTAL SECTION}

Catalyst Synthesis. Two $\mathrm{CuO} / \mathrm{CeO}_{2}$ and $\mathrm{CuO} /$ cryptomelane catalysts were prepared with equivalent $\mathrm{Cu}$ nominal target on each metal oxide support. $\mathrm{CeO}_{2}$ support was obtained via thermal decomposition of cerium(III) nitrate hexahydrate (Panreac) following a "flash" calcination at $500{ }^{\circ} \mathrm{C}$ in a preheated muffle furnace at 200 ${ }^{\circ} \mathrm{C} .{ }^{20,21}$ Synthetic cryptomelane was prepared following an adaptation from the so-called reflux method, procedure described by DeGuzman et al. ${ }^{22,23}$ Particularly, $11 \mathrm{~g}$ of manganese(II) acetate (Aldrich) were dissolved in $40 \mathrm{~g}$ of water in a solution with a $\mathrm{pH}$ fixed at 5 . After 30 min of reflux heating, potassium permanganate (Aldrich) solution $(6.5 \mathrm{~g} / 100 \mathrm{~mL})$ was introduced and the boiling mixture was maintained with vigorous stirring for $24 \mathrm{~h}$. The resulting dark-colored substance was filtered, washed until neutral $\mathrm{pH}$, and dried at $120{ }^{\circ} \mathrm{C}$ overnight; its calcination at $450{ }^{\circ} \mathrm{C}$ for $2 \mathrm{~h}$ led to cryptomelane.

Once supports were prepared, the grinded powders were impregnated with an aqueous solution of $\mathrm{Cu}\left(\mathrm{NO}_{3}\right)_{2} \cdot(5 \cdot 1 / 2) \mathrm{H}_{2} \mathrm{O}$ (Panreac) to a target $5 \%$ nominal w. $\mathrm{Cu}$ content following the incipient wetness impregnation methodology. The impregnated samples were calcined to obtain $\mathrm{CuO} / \mathrm{CeO}_{2}$ and $\mathrm{CuO} /$ cryptomelane catalysts following the same heating protocol as the respective supports.

CO-PROX Activity Tests. The prepared materials were tested in CO-PROX catalytic activity experiments using a regular $100 \mathrm{~mL} / \mathrm{min}$ flow of the gas reactant mixture $\left(2 \% \mathrm{CO}, 2 \% \mathrm{O}_{2}, 30 \% \mathrm{H}_{2}\right)$, set by means of Mass Flow Controllers (Bronkhorst). $150 \mathrm{mg}$ of catalyst was placed in a quartz fixed-bed reactor $(16 \mathrm{~mm}$ inner diameter, GHSV = $\sim 30,000 \mathrm{~h}^{-1}$ ) following a slow-pace heating ramp of $2{ }^{\circ} \mathrm{C} / \mathrm{min}$ up to $200{ }^{\circ} \mathrm{C}$. The reaction progress was monitored with a gas chromatograph HP model 6890 Plus Series coupled to a thermal conductivity detector. The effect of (1) $\mathrm{CO}_{2},(2) \mathrm{H}_{2} \mathrm{O}$ and (3) $\mathrm{CO}_{2}+$ $\mathrm{H}_{2} \mathrm{O}$ in the catalytic activity was studied by means of the introduction of $9 \% \mathrm{CO}_{2}, 5 \% \mathrm{H}_{2} \mathrm{O}$, and $9 \% \mathrm{CO}_{2}+5 \% \mathrm{H}_{2} \mathrm{O}$, respectively, in the reactant gas mixture feeding.

Catalyst Characterization. $\mathrm{N}_{2}$ adsorption-desorption isotherms were performed in an automatic volumetric system (Autosorb-6, Quantachrome) after outgassing the samples at $150{ }^{\circ} \mathrm{C}$ for $4 \mathrm{~h}$ (Figure S1, Table S1). Transmission electron microscopy (TEM) characterization was conducted using a JEOL (JEM-2010) microscope (Figure S2). Fresh and spent samples were characterized by means of X-ray diffraction (XRD) for the crystalline resolution using a Bruker D8-ADVANCE diffractometer using $\mathrm{Cu} \mathrm{K} \alpha$ radiation. Diffractograms were recorded at $2 \theta$ between 10 and $90^{\circ}$, with a step size of $0.05^{\circ}$ and a time of $3 \mathrm{~s}$ per step.

Temperature-programmed reduction experiments with $\mathrm{H}_{2}\left(\mathrm{H}_{2}-\right.$ TPR) were conducted in a Micromeritics Pulse Chemisorb 2705 instrument. $40 \mathrm{mg}$ of the catalyst was placed in a quartz tubular reactor under $40 \mathrm{~mL} / \mathrm{min}$ of $5 \% \mathrm{H}_{2} / \mathrm{Ar}$ gas mixture following a heating ramp of $10{ }^{\circ} \mathrm{C} / \mathrm{min}$.

Temperature-programmed desorption (TPD) experiments were conducted with $80 \mathrm{mg}$ of the catalyst after a pre-treatment at $400{ }^{\circ} \mathrm{C}$ for $30 \mathrm{~min}$ in a $100 \mathrm{~mL} / \mathrm{min}$ flow of Ar. Then, a saturation step with the selected gases was carried out, which consisted of heating the catalyst at $150{ }^{\circ} \mathrm{C}$ for $1 \mathrm{~h}$ under $100 \mathrm{~mL} / \mathrm{min}$ of $10 \% \mathrm{CO}_{2} / \mathrm{Ar}$ (for $\mathrm{CO}_{2}$-TPD), $5 \% \mathrm{H}_{2} \mathrm{O} / \mathrm{Ar}$ (for $\mathrm{H}_{2} \mathrm{O}$-TPD), or $10 \% \mathrm{CO}_{2}+5 \% \mathrm{H}_{2} \mathrm{O} / \mathrm{Ar}$ (for $\mathrm{CO}_{2}+\mathrm{H}_{2} \mathrm{O}$-TPD). After that, the gas mixture was switched to $\mathrm{Ar}$, and once $\mathrm{CO}_{2}$ and $\mathrm{H}_{2} \mathrm{O}$ signals were stabilized, the reactor was heated from 150 to $650{ }^{\circ} \mathrm{C}$ following a ramp of $10{ }^{\circ} \mathrm{C} / \mathrm{min}$ in 100 $\mathrm{mL} / \mathrm{min}$ of $\mathrm{Ar}$.

Isotopic ${ }^{36} \mathrm{O}_{2}$ Pulse Experiments. Isotopic exchange experiments were carried out with ${ }^{36} \mathrm{O}_{2}$ by means of an injection valve with a loop $(100 \mu \mathrm{L})$ and two high sensitivity pressure transducers. The experiments were carried out in a fixed-bed tubular quartz reactor with $80 \mathrm{mg}$ of catalyst in a constant $20 \mathrm{~mL} / \mathrm{min}$ of $1 \% \mathrm{CO}, 30 \% \mathrm{H}_{2}$ balanced $\mathrm{He}$ feeding mixture. The exhaust gases were monitored with MS, and the ${ }^{36} \mathrm{O}_{2}$ pulses (Isotec, 99\%; $100 \mu \mathrm{L}$ and 9 psi) were injected at 75,100 , and $150{ }^{\circ} \mathrm{C}$ once achieving signal stabilization. Prior to this, several pulses of $\operatorname{Ar}(100 \mu \mathrm{L}$ and $9 \mathrm{psi})$ were used as a test to confirm reproducibility of the method.

\section{RESULTS}

CO-PROX Activity Tests. Figure $1 \mathrm{a}, \mathrm{b}$ shows the temperature for the $50 \%$ of $\mathrm{CO}$ conversion $\left(T_{50}\right)$ along four consecutive CO-PROX catalytic runs, which allows us to evaluate the stability and recyclability of $\mathrm{CuO} / \mathrm{CeO}_{2}$ and $\mathrm{CuO} /$ cryptomelane catalysts. The CO-PROX light-off curves are compiled in Figure S3a,b,c,d, respectively. As shown, both catalysts reach $\mathrm{CO}$ conversion (and $\mathrm{CuO} /$ Cryptomelane catalysts are compiled in Figure S3a,b and Figure S3c,d, respectively). As shown, both catalysts reach $\mathrm{CO}$ conversion $\left(X_{\mathrm{CO}}\right)$ values of $94-98 \%$ in the low temperature window of CO-PROX regardless the conditions, besides $\mathrm{CO}$ selectivity (Sel.) is maintained close to the optimum (50\% according to the feeding $\mathrm{O}_{2} / \mathrm{CO}$ stoichiometry).

The inhibiting effect of the $\mathrm{CO}_{2}, \mathrm{H}_{2} \mathrm{O}$, and $\mathrm{CO}_{2}+\mathrm{H}_{2} \mathrm{O}$ mixture in the reactor feeding stream follows the trend $\mathrm{CO}_{2}<$ $\mathrm{H}_{2} \mathrm{O}<\mathrm{CO}_{2}+\mathrm{H}_{2} \mathrm{O}$ for both catalysts, in agreement with the reported literature. ${ }^{15,24-26}$ Interestingly, the impact of $\mathrm{H}_{2} \mathrm{O}$ in the $\mathrm{CO}$ oxidation catalytic activity results more detrimental than $\mathrm{CO}_{2}$ itself. In $\mathrm{CuO} / \mathrm{CeO}_{2}$, the interaction with $\mathrm{CO}_{2}$ leads to an intense carbonatation besides the formation of stable formates, carboxylates, and bicarbonates, which hamper $\mathrm{Cu}-$ $\mathrm{Ce}$ interaction and inhibit $\mathrm{CO}$ oxidation. ${ }^{24,25}$ On the contrary, the CO-PROX catalytic activity of $\mathrm{CuO} /$ cryptomelane is fairly not affected by $\mathrm{CO}_{2}$, but it is very sensitive to $\mathrm{H}_{2} \mathrm{O}$. On the other hand, $\mathrm{CO}_{2}+\mathrm{H}_{2} \mathrm{O}$ conditions lead to the strongest 

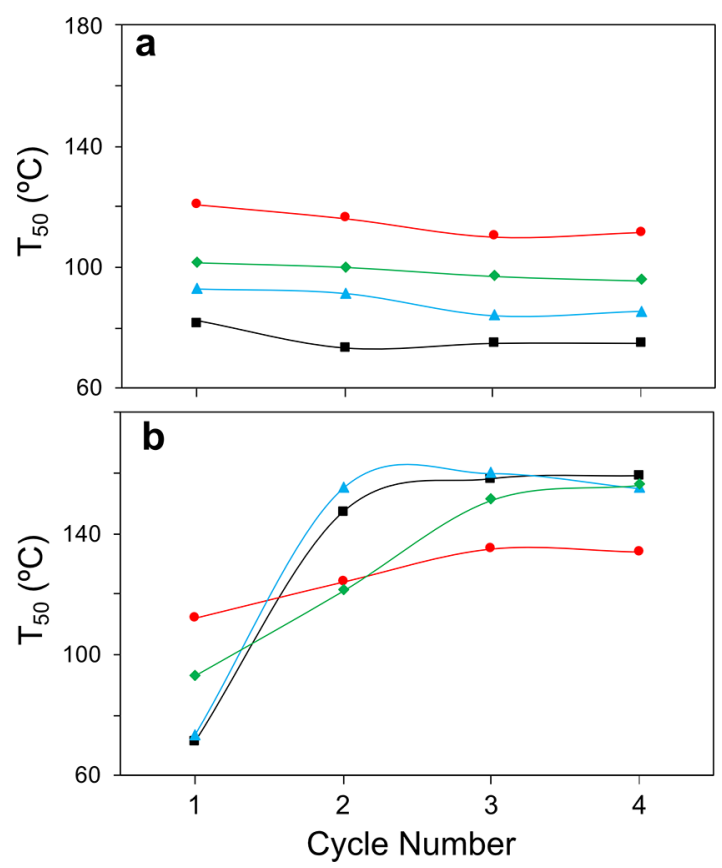

Figure 1. Temperature for the $50 \%$ of $\mathrm{CO}$ conversion $\left(T_{50}\right)$ in $1-4$ cycles of CO-PROX reaction in different environment mixtures: $\mathrm{CO}$ $+\mathrm{O}_{2}+\mathrm{H}_{2}$ (squares), $\mathrm{CO}+\mathrm{O}_{2}+\mathrm{H}_{2}+\mathrm{CO}_{2}$ (triangles), $\mathrm{CO}+\mathrm{O}_{2}+$ $\mathrm{H}_{2}+\mathrm{H}_{2} \mathrm{O}$ (diamonds), $\mathrm{CO}+\mathrm{O}_{2}+\mathrm{H}_{2}+\mathrm{CO}_{2}+\mathrm{H}_{2} \mathrm{O}$ (circles) for (a) $\mathrm{CuO} / \mathrm{CeO}_{2}$; (b) $\mathrm{CuO} /$ cryptomelane catalysts.

inhibition state, suggesting the participation of both species in co-adsorptive processes. ${ }^{15,27}$

According to Figure $1, \mathrm{CuO} / \mathrm{CeO}_{2}$ presents a stable behavior within four cycles of reaction in all the tested conditions, while $\mathrm{CuO} /$ cryptomelane suffers from a deactivating process of different magnitude as seen by the $T_{50}$ increase alongside the number of reaction runs. This degradation is spurred by ongoing oxidation-reduction cycles during $\mathrm{CO}$ PROX that lead to the inactive $\mathrm{Mn}_{3} \mathrm{O}_{4}{ }^{8,28}$ which was proven to be partially reversible by means of oxidative regeneration treatments. $^{29}$

Comparing both catalysts, $\mathrm{CuO} /$ cryptomelane presents an enhanced catalytic activity with regard to $\mathrm{CuO} / \mathrm{CeO}_{2}$ in a first run for all the set of conditions. However, the deactivation of $\mathrm{CuO} /$ cryptomelane leads to the opposite trend beyond the second cycle. $\mathrm{CO}_{2}+\mathrm{H}_{2} \mathrm{O}$ conditions confer the greatest stability to $\mathrm{CuO} /$ cryptomelane and in result, the best performance in the fourth cycle. In this atmosphere, $\mathrm{CuO}$ / cryptomelane displays an admirable activity as compared with $\mathrm{CuO} / \mathrm{CeO}_{2}\left(T_{50}\right.$ of 134 and $117{ }^{\circ} \mathrm{C}$, respectively $)$. Because CO-PROX reaction under $\mathrm{CO}_{2}$ and $\mathrm{H}_{2} \mathrm{O}$ presence is the most challenging, but also the most representative of the realistic operation, the promising potential of $\mathrm{CuO} /$ cryptomelane deserves to be further investigated.

Understanding the Catalyst Stability under $\mathrm{CO}_{2}$ and $\mathrm{H}_{2} \mathrm{O}$ Mixtures. As typical for $\mathrm{Mn}^{4+}$-based minerals, cryptomelane is dark-colored and operando infrared spectroscopy measures fail due to its high absorption, showing blackout IR spectra. Therefore, the study of the reaction mechanism must be assessed by alternative and complementary techniques.

The Supporting Information document contains the characterization results of fresh and spent catalyst samples in the different conditions tested. Namely, XRD (Figure S4a,b,
Tables S2 and S3) and $\mathrm{H}_{2}$-TPR (Figure S5a,b) which confirm that $\mathrm{CuO} / \mathrm{CeO}_{2}$ catalyst presents a robust crystalline structure, whereas $\mathrm{CuO} /$ cryptomelane displays a poor stability under CO-PROX reaction in $\mathrm{CO}+\mathrm{O}_{2}+\mathrm{H}_{2}$ conditions, after which, $\mathrm{Mn}_{3} \mathrm{O}_{4}$ (hausmannite) is the main crystalline phase. The transition from cryptomelane $\left(\mathrm{K}_{\mathrm{x}} \mathrm{Mn}_{8} \mathrm{O}_{16}\right)$ to $\mathrm{Mn}_{3} \mathrm{O}_{4}$ involves the collapse of the characteristic $2 \times 2$ tunnels of cryptomelane besides the reduction of $\mathrm{Mn}$ cations from an average oxidation state of $c a .+3.8$ to +2.5 . The degradation of the cryptomelane microstructure occurs when the intratunnel $\mathrm{K}$ is segregated to the outer surface and probably released in the form of $\mathrm{K}$ volatile species. ${ }^{30,31}$ The loss of charge-compensating $\mathrm{K}$ species leads to the reduction of the manganese ions left upon cryptomelane collapse. ${ }^{32,33}$ Figure S2e,f shows TEM images of the deactivated $\mathrm{CuO} /$ cryptomelane catalyst, displaying nonaggregated $\mathrm{Mn}$ oxide particles around the deteriorated nanorod array. In our previous work, ${ }^{29}$ we studied the $\mathrm{CuO} /$ cryptomelane deactivated material left upon CO-PROX cycles, and no significant textural differences compared to the fresh sample related to this transition phase were found. However, we reported evidences of potassium segregation, manganese reduction, and the formation of copper species with high charge density. The presence of these partially reduced copper species with the atypical XPS binding energy of $c a .930 .5 \mathrm{eV}$ is well reported for the hopcalite $\mathrm{CuMn}_{2} \mathrm{O}_{4}$ spent and deactivated material, which suffers an amorphous to crystalline transition. ${ }^{34,35}$ In the case of deactivated $\mathrm{CuO} /$ cryptomelane samples, $\mathrm{Cu}^{n+}$ species at that low binding energy are ascribed to $\mathrm{Cu}^{+}$being located in an octahedral site in the spinel structure, subjected to a larger extra-atomic relaxation energy. ${ }^{17,36}$ Finally, as in the case of the $\mathrm{CuO} / \mathrm{CeO}_{2}$ catalyst, tenorite peaks from the segregated $\mathrm{CuO}$ phase is not detectable in the X-ray diffractograms of $\mathrm{CuO} /$ cryptomelane (see Figure $54 a, b)$. The absence of $\mathrm{CuO}$ peaks reveals that the copper phase is well dispersed before and after the reaction runs. On the other hand, the co-addition of $\mathrm{CO}_{2}+\mathrm{H}_{2} \mathrm{O}$ in the CO-PROX gas reactant mixture leads to the preservation of the cryptomelane structure (see Table S3).

Regarding the redox features, $\mathrm{H}_{2}$-TPR profiles (Figure $\mathrm{S} 5 \mathrm{a}, \mathrm{b})$ reveal that $\mathrm{CuO} / \mathrm{CeO}_{2}$ samples experience changes in $\mathrm{Cu}-\mathrm{Ce}$ interaction after the CO-PROX reaction cycles, which are hints of $\mathrm{CuO}$ sintering or $\mathrm{Cu}-\mathrm{Ce}$ contact modification. ${ }^{37,38}$ However, these do not reflect into any sort of activity loss. For $\mathrm{CuO} /$ cryptomelane, $\mathrm{H}_{2}$-TPR profiles exhibit large differences depending on the catalyst state. Nevertheless, the spent sample in $\mathrm{CO}_{2}+\mathrm{H}_{2} \mathrm{O}$ conditions shows discrepancies with the fresh sample; the manganese reduction events roughly keep the shape and position in the profile. For the sample used in the experiments free of $\mathrm{CO}_{2}+\mathrm{H}_{2} \mathrm{O}$, the reduction profile presents a very different aspect, which can be attributed to the cryptomelane phase distortion and reduction toward the hausmannite phase.

TPD experiments (Figure $2 \mathrm{a}-\mathrm{f}$ ) for $\mathrm{CuO} / \mathrm{CeO}_{2}$ and $\mathrm{CuO} /$ cryptomelane after $\mathrm{CO}_{2}, \mathrm{H}_{2} \mathrm{O}$, and $\mathrm{CO}_{2}+\mathrm{H}_{2} \mathrm{O}$ exposures provide relevant insights about the catalyst interaction with $\mathrm{CO}_{2}$ and $\mathrm{H}_{2} \mathrm{O}$. As depicted, $\mathrm{CeO}_{2}$ has a great capacity to stabilize carbonaceous species on surface due to its high basicity. On the contrary, cryptomelane has very moderate affinity for $\mathrm{CO}_{2}$, in agreement with the low impact of $\mathrm{CO}_{2}$ addition in the CO-PROX activity tests. In both cases, $\mathrm{H}_{2} \mathrm{O}$ is co-released, which can be attributed to the depletion of the inherently present hydroxyls upon carbonate and bicarbonate decomposition. Analogously, after $\mathrm{H}_{2} \mathrm{O}$ saturation, $\mathrm{H}_{2} \mathrm{O}$ and 

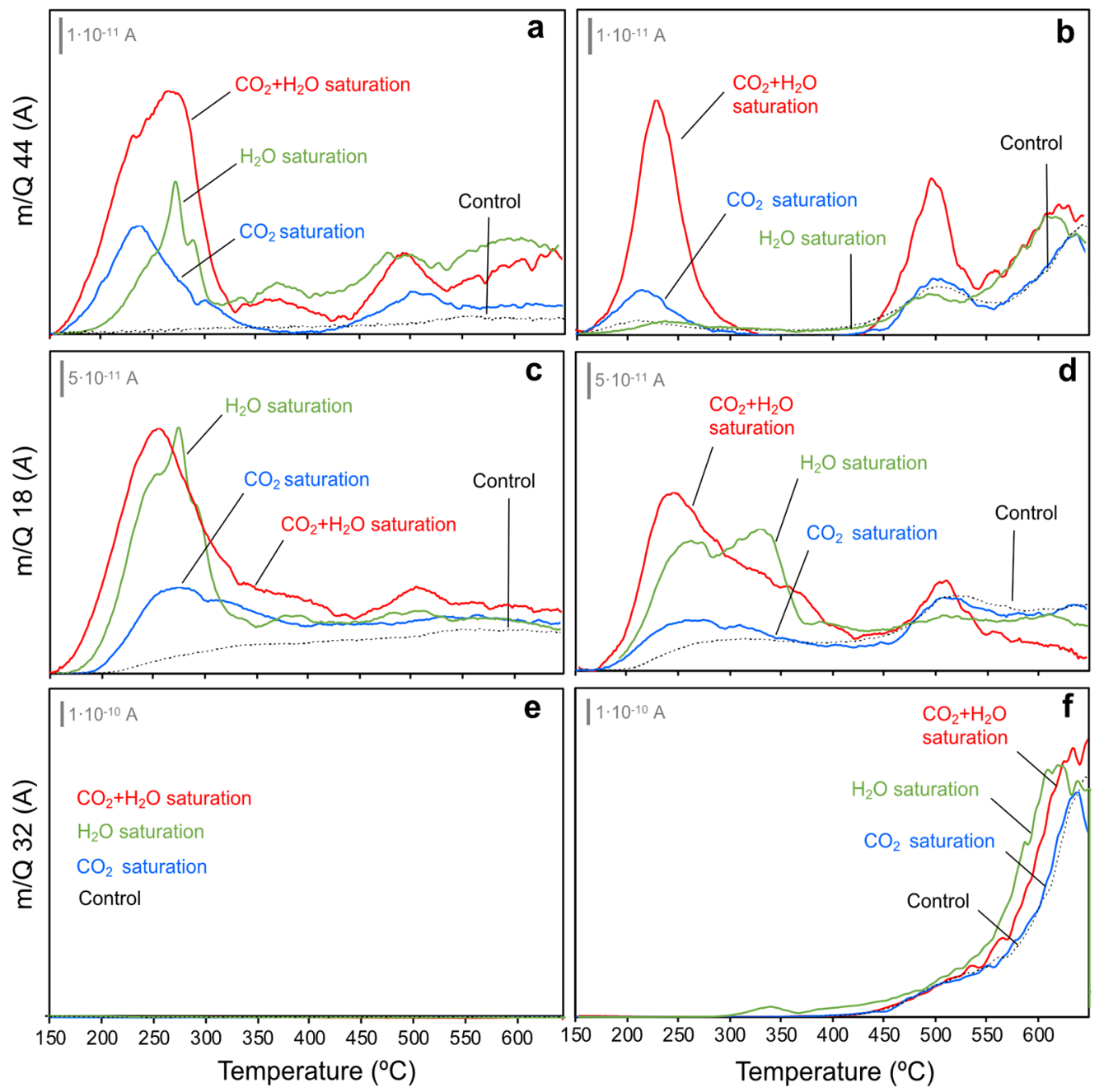

Figure 2. Monitored MS signals (a,b) 44, $\mathrm{CO}_{2} ;(\mathrm{c}, \mathrm{d}) 18, \mathrm{H}_{2} \mathrm{O}$; and $(\mathrm{e}, \mathrm{f}) 32, \mathrm{O}_{2}$ for $(\mathrm{a}, \mathrm{c}, \mathrm{e}) \mathrm{CuO} / \mathrm{CeO}_{2}$; and $(\mathrm{b}, \mathrm{d}, \mathrm{f}) \mathrm{CuO} /$ cryptomelane catalysts in $\mathrm{CO}_{2}$-TPD; $\mathrm{H}_{2} \mathrm{O}$-TPD; and $\left(\mathrm{CO}_{2}+\mathrm{H}_{2} \mathrm{O}\right)$-TPD experiments.

$\mathrm{CO}_{2}$ co-evolve and $\mathrm{CO}_{2}-\mathrm{H}_{2} \mathrm{O}$ interaction is maximized, as $\mathrm{CuO} / \mathrm{CeO}_{2}$ exhibits in these conditions a larger $\mathrm{CO}_{2}$ release than after $\mathrm{CO}_{2}$ saturation itself. ${ }^{39}$ Thus, $\mathrm{H}_{2} \mathrm{O}$ in contact to $\mathrm{CuO} / \mathrm{CeO}_{2}$ catalyst may favor the release of intrinsically present stable carbonates.

In the case of $\mathrm{CuO} /$ cryptomelane, the $\mathrm{CO}_{2}-\mathrm{H}_{2} \mathrm{O}$ co-release upon the individual gas exposure is not so relevant, and on the other hand, cryptomelane is much more prone to interact with $\mathrm{H}_{2} \mathrm{O}$ than with $\mathrm{CO}_{2}$. However, the concomitant addition of $\mathrm{CO}_{2}+\mathrm{H}_{2} \mathrm{O}$ leads to a sharp growth of $\mathrm{CO}_{2}$ and $\mathrm{H}_{2} \mathrm{O}$ release, which is indicative of a favored $\mathrm{CO}_{2}-\mathrm{H}_{2} \mathrm{O}$ co-adsorption as in the case of $\mathrm{CuO} / \mathrm{CeO}_{2}$. For $\mathrm{CuO} /$ cryptomelane, since it shows a low affinity toward bare $\mathrm{CO}_{2}$ chemisorption, $\mathrm{CO}_{2}$ is inferred to be retained as hydrogenated carbon intermediates, such as bicarbonates on the cryptomelane acidic surface.

Finally, the $\mathrm{O}_{2}$ profile (MS signal of 32, Figure 2e) shows that $\mathrm{CuO} / \mathrm{CeO}_{2}$ is thermally stable since it presents a negligible flat product release up to the maximum temperature of the experiment (i.e., $650{ }^{\circ} \mathrm{C}$ ). In contrast, $\mathrm{CuO} /$ cryptomelane displays a significant $\mathrm{O}_{2}$ release (Figure 2f) which starts decomposing above $450{ }^{\circ} \mathrm{C}$. Remarkably, the $\mathrm{CuO} /$ cryptomelane decomposition occurs equally regardless the nature of the saturation treatment, which differs from the enhanced stability assessed for $\mathrm{CuO} /$ cryptomelane in the $\mathrm{CO}_{2}$ $+\mathrm{H}_{2} \mathrm{O}$ CO-PROX tests. Thus, the positive effect of $\mathrm{CO}_{2}+$
$\mathrm{H}_{2} \mathrm{O}$ on cryptomelane during the CO-PROX reaction cannot be merely superficial, and other factors must be at play involving the catalyst oxidation-reduction cyclability.

Isotopic ${ }^{36} \mathrm{O}_{2}$ Pulse Experiments. Pulse oxygen isotopic experiments in $\mathrm{CO}-\mathrm{PROX}$ conditions at selected temperatures were conducted for both $\mathrm{CuO} / \mathrm{CeO}_{2}$ and $\mathrm{CuO} /$ cryptomelane samples (Figure $3 \mathrm{a}-\mathrm{f}$ ). For the critical comparison between both catalysts, the monitored $\mathrm{MS}$ signals were normalized in terms of total $\mathrm{O}$ species $\left(\mathrm{CO}_{2}+\mathrm{H}_{2} \mathrm{O}+\mathrm{O}_{2}\right)$. The time evolution of the pulses at different temperatures is depicted in Figure $3 \mathrm{a}-\mathrm{f}$, while the quantification of the released products is presented in Figure 4a,b. Noticeably, in the $\mathrm{CuO} / \mathrm{CeO}_{2}$ catalyst, no trace of $\mathrm{O}_{2}$ signals was found at any of the tested temperatures after the ${ }^{36} \mathrm{O}_{2}$ pulse. This indicates that the catalyst fully uptakes the incoming $\mathrm{O}_{2}$, accommodating oxygen into the lattice as the anionic vacancies created upon the reducing conditions of the experiment are refilled. This labile restorage after the isotopic oxygen pulse leads to the destabilization of the adsorbed $\mathrm{CO}$ and $\mathrm{H}_{2}$ molecules, being released as and their oxidation products (i.e., $\mathrm{CO}_{2}$ and $\mathrm{H}_{2} \mathrm{O}$ ). The analysis of the product distribution evolved reveals that $\mathrm{CO}$ and $\mathrm{H}_{2}$ oxidation reactions occur mainly involving lattice oxygen $\left({ }^{16} \mathrm{O}\right)$, as well reported for $\mathrm{CuO} / \mathrm{CeO}_{2}$ catalysts displaying a Mars-van Krevelen (MVK). ${ }^{40-42}$ In this regard, the temperature does not affect significantly the isotopic 


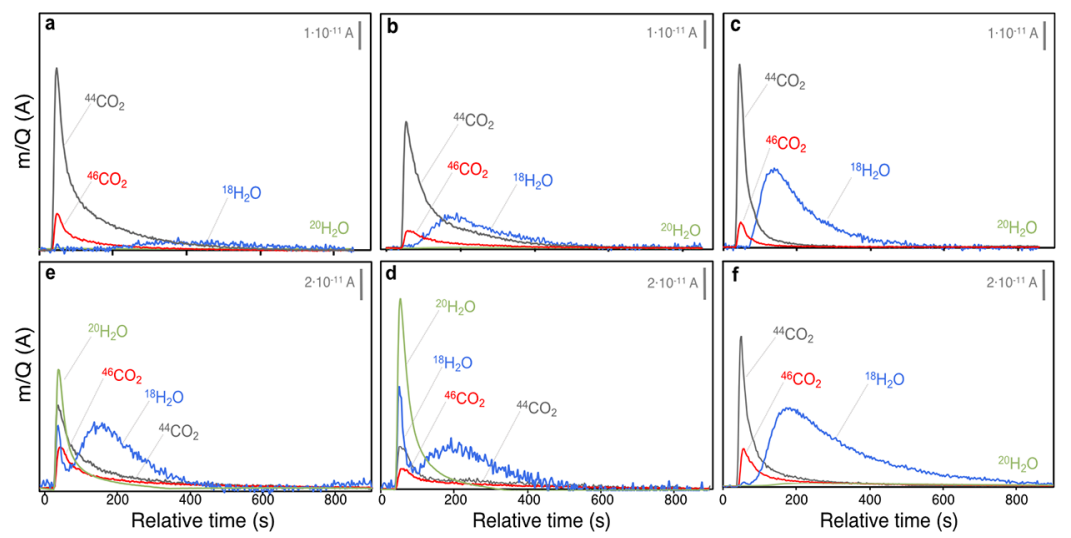

Figure 3. MS signals after ${ }^{36} \mathrm{O}_{2}$ pulses in CO-PROX conditions with $(\mathrm{a}-\mathrm{c}) \mathrm{CuO} / \mathrm{CeO}_{2}$ and $(\mathrm{d}-\mathrm{f}) \mathrm{CuO} /$ cryptomelane catalyst at $(\mathrm{a}$,d) 75 , (b,e) 100 , and $(\mathrm{c}, \mathrm{f}) 150^{\circ} \mathrm{C}$. Zero-time refers to the pulse injection in the reactor.

product share within the $75-150{ }^{\circ} \mathrm{C}$ range, but it does to the global yield to $\mathrm{CO}_{2}$ and $\mathrm{H}_{2} \mathrm{O}$, in good correlation with the selectivity fall observed in fixed-bed catalytic. Thus, ${ }^{20} \mathrm{H}_{2} \mathrm{O}$ is not detected, whereas the release of ${ }^{18} \mathrm{H}_{2} \mathrm{O}$ is delayed in time compared to $\mathrm{CO}_{2}$-type products. This decoupling of the $\mathrm{CO}_{2}$ and $\mathrm{H}_{2} \mathrm{O}$ evolution can be attributed to greater desorption limitations of $\mathrm{H}_{2} \mathrm{O}$ on the surface of $\mathrm{CeO}_{2}$.

For the $\mathrm{CuO} /$ cryptomelane catalyst, Figure $3 \mathrm{~d}-\mathrm{f}$ shows the evolved products after the ${ }^{36} \mathrm{O}_{2}$ pulses at the different temperatures, and significant differences are found when compared to $\mathrm{CuO} / \mathrm{CeO}_{2}$. First, the release of a large amount of $\mathrm{H}_{2} \mathrm{O}$ at low temperatures disrupts the well-correlated $\mathrm{CO}$ selectivity profiles of pulse experiments to fix-bed catalytic tests as in the $\mathrm{CuO} / \mathrm{CeO}_{2}$ catalyst. Furthermore, the distribution of $\mathrm{CO}_{2}$ and $\mathrm{H}_{2} \mathrm{O}$ products is a mixture between isotopic and nonisotopic, rather than clearly non-isotopic as for $\mathrm{CuO} / \mathrm{CeO}_{2}$, which indicates a poorer oxygen exchange capacity for $\mathrm{CuO} /$ cryptomelane. In order to evaluate this, Figure $4 a, b$ shows for both catalysts the integrated signals for the released products from $\mathrm{H}_{2} \mathrm{O}$ and $\mathrm{CO}_{2}$ formation upon $\mathrm{H}_{2}$ and $\mathrm{CO}$ oxidation after the pulse (solid symbols), as well as the overall outlet $\mathrm{H}_{2} \mathrm{O}$, $\mathrm{CO}_{2}$, and $\mathrm{O}_{2}$ measured (open symbols).

As depicted, $\mathrm{CO}_{2}$ and $\mathrm{H}_{2} \mathrm{O}$ profiles are more complex in the case of $\mathrm{CuO} /$ cryptomelane and the effect of temperature is more relevant in the distribution of the evolved species. In this case, upon interaction with the $\mathrm{CuO} /$ cryptomelane surface, most of the incoming isotopic ${ }^{36} \mathrm{O}_{2}$ molecules leads to ${ }^{20} \mathrm{H}_{2} \mathrm{O}$, which is released after the pulse with no apparent desorption limitations. On the other hand, the oxygen pulse destabilizes the intrinsically present $\mathrm{H}_{2} \mathrm{O}$ molecules, resulting in a large ${ }^{18} \mathrm{H}_{2} \mathrm{O}$ (non-isotopic) co-emission. In contrast with ${ }^{20} \mathrm{H}_{2} \mathrm{O}$, two different contributions of ${ }^{18} \mathrm{H}_{2} \mathrm{O}$ are discerned, being one anticipated and released at the same time of ${ }^{20} \mathrm{H}_{2} \mathrm{O}$ and $\mathrm{CO}_{2}$ species, and the other retarded as $\mathrm{H}_{2} \mathrm{O}$ in the $\mathrm{CuO} / \mathrm{CeO}_{2}$ catalyst. According to the $\mathrm{H}_{2} \mathrm{O}$ desorption profile (Figure 2e), $\mathrm{CuO} /$ cryptomelane would release two types of $\mathrm{H}_{2} \mathrm{O}$ in the low-temperature region, attributed to surface-related water and water bounded inside the $2 \times 2$ tunnels. Hence, the first $\mathrm{H}_{2} \mathrm{O}$ contribution must be tentatively assigned to the mobilization of the intrinsic intratunnel water molecules that undergo a labile exchange with the incoming ${ }^{36} \mathrm{O}_{2}$ molecules, resulting in a sharp co-emission of ${ }^{18} \mathrm{H}_{2} \mathrm{O}$ and ${ }^{20} \mathrm{H}_{2} \mathrm{O}$. As it has been discussed elsewhere, ${ }^{31,33}$ the activity of the $\mathrm{CuO} /$ cryptomelane catalyst is related to the presence of highly mobile water species hosted in the tunnels, which provide good ionic

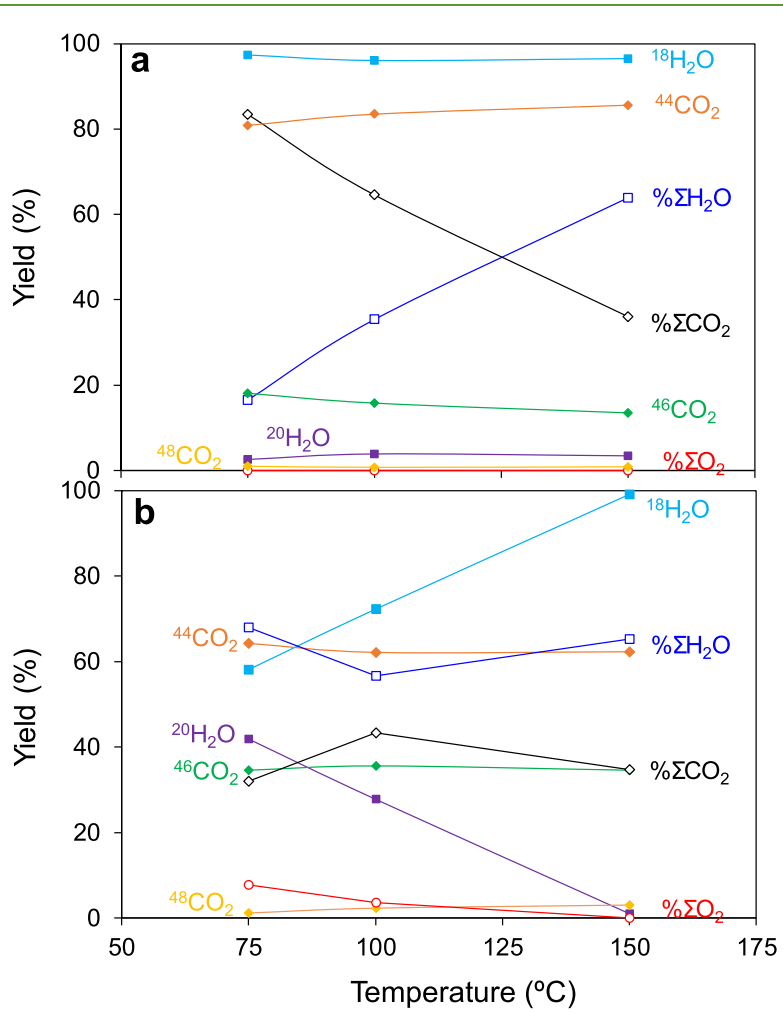

Figure 4. MS-normalized signals after ${ }^{36} \mathrm{O}_{2}$ pulses in CO-PROX conditions with (a) $\mathrm{CuO} / \mathrm{CeO}_{2}$, (b) $\mathrm{CuO} /$ cryptomelane catalyst at 75,100 , and $150{ }^{\circ} \mathrm{C}$. (Solid symbols): overall $\mathrm{O}_{2}$ released species in the outlet flow; (open symbols): isotopic distribution among $\mathrm{H}_{2} \mathrm{O}$ and $\mathrm{CO}_{2}$ species.

mobility and stabilize the cryptomelane framework. Thus, the $\mathrm{CuO} /$ cryptomelane crystalline nature and catalytic activity features rely on such bounded $\mathrm{H}_{2} \mathrm{O}$ molecules, as partial $\mathrm{O}$ exchange in water is indeed observed. The temperature has an effect in lowering the evolution of the anticipated $\mathrm{H}_{2} \mathrm{O}$, which is in agreement with the cryptomelane collapse toward the formation of the average reduced $\mathrm{Mn}_{3} \mathrm{O}_{4}$ spinel phase, as a result of the massive water loss caused by the CO-PROX reaction conditions. So that, at high temperatures in the $\mathrm{CO}+$ $\mathrm{H}_{2}$ conditions of the pulse experiments, the $\mathrm{CuO} /$ cryptomelane catalyst is gradually reduced and consequently, the amount of released water decreases, until at $150{ }^{\circ} \mathrm{C}$, cryptomelane is in overall reduced. In such state, intra-tunnel 
water species are not found to be released either because they are totally depleted or because the remaining species is so tightly bounded that are not mobilized after the pulse. Thus, only beyond $150{ }^{\circ} \mathrm{C}$, the outlet water comes solely from $\mathrm{H}_{2}$ oxidation reaction, and the release of such delayed $\mathrm{H}_{2} \mathrm{O}$ evidently has a more relevant contribution in the overall $\mathrm{CO}_{2}+$ $\mathrm{H}_{2} \mathrm{O}$ distribution than in the equivalent conditions for $\mathrm{CuO} /$ $\mathrm{CeO}_{2}$. This apparent lower $\mathrm{CO}$ selectivity of $\mathrm{CuO} /$ cryptomelane needs to be rationalized, given the large affinity of $\mathrm{CuO} /$ cryptomelane to water and the strong driving force found that releases intratunnel hosted species in the conditions of the experiment. On the contrary, the isotopic $\mathrm{CO}_{2}$ components are free of this masking effect from cryptomelane intrinsic water. Thus, compared to $\mathrm{CuO} / \mathrm{CeO}_{2}, \mathrm{CuO} /$ cryptomelane exhibits a lowered contribution for the nonisotopic ${ }^{44} \mathrm{CO}_{2}$ species, that is, lesser participation in the MVK mechanism due to a less active lattice oxygen species. As a result, whereas $\mathrm{CuO} / \mathrm{CeO}_{2}$ efficiently uptakes the pulsed $\mathrm{O}_{2}$ molecules in the anionic lattice vacancies, $\mathrm{CuO} /$ cryptomelane exchanges $\mathrm{O}$ from structural water, which is partially released as isotopic ${ }^{20} \mathrm{H}_{2} \mathrm{O}$ without accommodating the integrity of the $\mathrm{O}_{2}$ pulse. In this case, the $\mathrm{O}$ restorage from the pulse is high, but not complete at 75 and $100{ }^{\circ} \mathrm{C}$ (see Figure S6) since the $\mathrm{O}$-catalyst preferential interaction occurs within the intratunnel water molecules rather than through direct O-lattice restoration in the $\mathrm{MnO}_{6}$ octahedra framework. Finally, at $150{ }^{\circ} \mathrm{C}$, the system reaches the non-selective regime, where producing $\mathrm{H}_{2} \mathrm{O}$ is released as the major reaction product. Onwards, $\mathrm{H}_{2} \mathrm{O}$ products are majority regardless of the temperature.

\section{GENERAL DISCUSSION}

The relative participation of lattice oxygen in the $\mathrm{CO}$ oxidation (MVK) mechanism of reaction is greater in the $\mathrm{CuO} / \mathrm{CeO}_{2}$ catalyst than in the $\mathrm{CuO} /$ cryptomelane, evidenced by the larger emission of non-isotopic products after the pulses. In contact with $\mathrm{CuO} /$ cryptomelane, incoming $\mathrm{O}_{2}$ molecules preferentially interact with the labile $\mathrm{H}_{2} \mathrm{O}$ species hosted in the tunnels, which are a key element of cryptomelane good oxidation activity. These species turn into quick oxygen exchange sites and mediate into the oxygen restoration, besides preventing extensive $\mathrm{H}_{2} \mathrm{O}$ release toward cryptomelane collapse. When $\mathrm{H}_{2} \mathrm{O}$ is supplied in the CO-PROX reactor, $\mathrm{CuO} /$ cryptomelane maintains a better performance along catalytic cycles, given its faster reoxidation capacity mediated via $\mathrm{H}_{2} \mathrm{O}$. The positive complementary effect of $\mathrm{CO}_{2}$ cannot be ruled out since the best performance at the fourth cycle occurs in $\mathrm{CO}_{2}+\mathrm{H}_{2} \mathrm{O}$ conditions, as shown in Figure 1b. A possible explanation is the maximization of the $\mathrm{H}_{2} \mathrm{O}$ retention capacity by the maximization of $\mathrm{H}_{2} \mathrm{O}$ interaction with the cryptomelane surface promoted when $\mathrm{H}_{2} \mathrm{O}$ and $\mathrm{CO}_{2}$ are co-supplied, in agreement with TPD results. TPD profiles also show that $\mathrm{CO}_{2}$ $+\mathrm{H}_{2} \mathrm{O}$ saturation incentivizes the low-temperature water desorption $\left(150-300{ }^{\circ} \mathrm{C}\right)$, attributed to surface water, in detriment of the higher temperature contribution (300-375 ${ }^{\circ} \mathrm{C}$ ), attributed to intratunnel water. Hence, $\mathrm{CO}_{2}$ presence aids to stabilize intratunnel water, preventing its release after $\mathrm{CO}_{2}+$ $\mathrm{H}_{2} \mathrm{O}$ contact when compared to lone $\mathrm{H}_{2} \mathrm{O}$. Cryptomelane stability is improved. The characteristic redox features are better maintained with the co-addition of $\mathrm{CO}_{2}$, as well as $\mathrm{CO}_{2}$ retention is enlarged in the stabilization of hydrogencarbonated intermediates. In turn, the surface coverage of labile carbonaceous intermediates with a facile desorption protects the O-lattice abstraction and cryptomelane reduction upon $\mathrm{CO}$ and $\mathrm{H}_{2}$ oxidation reactions, resulting in a hindered activity, but eventually a greater stability.

\section{CONCLUSIONS}

The CO-PROX catalytic performance and reaction mechanism have been addressed in $\mathrm{CuO} / \mathrm{CeO}_{2}$ and $\mathrm{CuO} /$ cryptomelane catalysts. In the first run, the catalytic activities of $\mathrm{CuO} / \mathrm{CeO}_{2}$ and $\mathrm{CuO} /$ cryptomelane are comparable, being both excellent materials for this application even in real operation conditions, including $\mathrm{CO}_{2}+\mathrm{H}_{2} \mathrm{O}$ in the feeding stream. In $\mathrm{CuO} / \mathrm{CeO}_{2}$, both $\mathrm{CO}_{2}$ and $\mathrm{H}_{2} \mathrm{O}$ are inhibited by surface blockage, where $\mathrm{H}_{2} \mathrm{O}$ has more impact. On the contrary, $\mathrm{CuO} /$ cryptomelane is not affected by $\mathrm{CO}_{2}$ presence but strongly inhibited by $\mathrm{H}_{2} \mathrm{O}$. In terms of cyclability and reusability, $\mathrm{CuO} / \mathrm{CeO}_{2}$ maintains the activity along, at least, four catalytic cycles regardless of the ambient conditions. However, $\mathrm{CuO} /$ cryptomelane suffers from severe deactivation related to structural collapse and partial reduction from cryptomelane phase $\left(\mathrm{MnO}_{2}\right)$ to hausmannite $\left(\mathrm{Mn}_{3} \mathrm{O}_{4}\right)$, and the extent of such deactivation depends on the inlet gas mixture. Namely, $\mathrm{CO}_{2}+\mathrm{H}_{2} \mathrm{O}$ conditions prevent $\mathrm{CuO} /$ cryptomelane decomposition, enabling to achieve the best catalytic performance at the fourth cycle, conditions where the near-optimal $\mathrm{CuO} / \mathrm{CeO}_{2}$ catalyst exhibits its worst catalytic behavior.

In conclusion, $\mathrm{CuO} /$ cryptomelane demonstrates to be a potential competitor to $\mathrm{CuO} / \mathrm{CeO}_{2}$ in $\mathrm{CO}-\mathrm{PROX}$ technologies under realistic operation conditions. This outcome opens up an era of possibilities toward a sustainable non-REE based catalysis yet to scale and test in the future. Up to now, green and efficient catalysts based on active copper-manganese formulation designed in this study are proven to be sufficiently good candidates, once established the best reaction protocols. Future studies will allow improvement on the stability in long term and cyclic operations of cryptomelane-based systems, as well as to broaden the battery of active materials of similar nature. This knowledge can be extended to analogue studies of other minerals toward the design of the optimum $\mathrm{Cu}-\mathrm{Mn}$ catalytic synergism.

\section{ASSOCIATED CONTENT}

\section{sI Supporting Information}

The Supporting Information is available free of charge at https://pubs.acs.org/doi/10.1021/acssuschemeng.1c00343.

Physicochemical characterization of the catalysts: $\mathrm{N}_{2}$ adsorption at $-196{ }^{\circ} \mathrm{C}$, transmission electron images, as well as CO-PROX catalytic activity results, XRD and $\mathrm{H}_{2}$-TPR results from fresh and spent samples, and additional material from isotopic oxygen pulse experiments (PDF)

\section{AUTHOR INFORMATION}

\section{Corresponding Author}

Arantxa Davó-Quiñonero - Inorganic Chemistry

Department, University of Alicante, E-03080 Alicante,

Spain; 이이이.org/0000-0001-9776-3458;

Email: arantxa.davo@tcd.ie

\section{Authors}

Sergio López-Rodríguez - Inorganic Chemistry Department, University of Alicante, E-03080 Alicante, Spain 
Esther Bailón-García - Inorganic Chemistry Department, University of Alicante, E-03080 Alicante, Spain; (1) orcid.org/0000-0001-8418-8714

Dolores Lozano-Castelló - Inorganic Chemistry Department, University of Alicante, E-03080 Alicante, Spain

Agustín Bueno-López - Inorganic Chemistry Department, University of Alicante, E-03080 Alicante, Spain; (1) orcid.org/0000-0002-5434-6459

Complete contact information is available at: https://pubs.acs.org/10.1021/acssuschemeng.1c00343

\section{Author Contributions}

The manuscript was written through contributions of all authors. All authors have given approval to the final version of the manuscript. All authors contributed equally to this work.

Notes

The authors declare no competing financial interest.

\section{ACKNOWLEDGMENTS}

The authors thank the financial support of the Spanish Ministry of Economy and Competitiveness (Project CTQ2015-67597-C2-2-R and grant FJCI-2015-23769), the Spanish Ministry of Science and Innovation (PID2019105960RB-C22), Spanish Ministry of Education (FPU14/ 01178), Generalitat Valenciana (Project PROMETEO/2018/ 076), and the EU (FEDER funding).

\section{REFERENCES}

(1) European Commission. Critical materials for strategic technologies and sectors in the EU-a foresight study. 2020. https:// ec.europa.eu/docsroom/documents/42881 (accessed October 2020).

(2) Mancheri, N. A.; Sprecher, B.; Bailey, G.; Ge, J.; Tukker, A. Effect of Chinese Policies on Rare Earth Supply Chain Resilience. Resour., Conserv. Recycl. 2019, 142, 101-112.

(3) Wan, R.; Wen, J.-F. The Environmental Conundrum of Rare Earth Elements. Environ. Resour. Econ. 2017, 67, 157-180.

(4) Machacek, E.; Richter, J.; Lane, R. Governance and Risk-Value Constructions in Closing Loops of Rare Earth Elements in Global Value Chains. Resources 2017, 6, 59-74.

(5) Smith, B. J.; Eggert, R. G. Costs, Substitution, and Material Use: The Case of Rare Earth Magnets. Environ. Sci. Technol. 2018, 52, 3803-3811.

(6) Trovarelli, A. Catalysis by Ceria and Related Materials; Catalytic Science Series; Imperial College Press, 2002; Vol. 1.

(7) Liu, B.; Zhang, Y.; Lu, M.; Su, Z.; Li, G.; Jiang, T. Extraction and Separation of Manganese and Iron from Ferruginous Manganese Ores: A Review. Miner. Eng. 2019, 131, 286-303.

(8) Dey, S.; Praveen Kumar, V. V. The Performance of Highly Active Manganese Oxide Catalysts for Ambient Conditions Carbon Monoxide Oxidation. Curr. Res. Green Sustain. Chem. 2020, 3, 100012-100027.

(9) Almquist, C.; Krekeler, M.; Jiang, L. An Investigation on the Structure and Catalytic Activity of Cryptomelane-Type Manganese Oxide Materials Prepared by Different Synthesis Routes. Chem. Eng. J. 2014, 252, 249-262.

(10) Luo, J.; Zhang, Q.; Garcia-Martinez, J.; Suib, S. L. Adsorptive and Acidic Properties, Reversible Lattice Oxygen Evolution, and Catalytic Mechanism of Cryptomelane-Type Manganese Oxides as Oxidation Catalysts. J. Am. Chem. Soc. 2008, 130, 3198-3207.

(11) Duan, N.; Suib, S. L.; O'Young, C.-L. Sol-Gel Synthesis of Cryptomelane, an Octahedral Molecular Sieve. J. Chem. Soc., Chem. Commun. 1995, 13, 1367-1368.

(12) Hernández, W. Y.; Centeno, M. A.; Romero-Sarria, F.; Ivanova, S.; Montes, M.; Odriozola, J. A. Modified Cryptomelane-Type
Manganese Dioxide Nanomaterials for Preferential Oxidation of CO in the Presence of Hydrogen. Catal. Today 2010, 157, 160-165.

(13) Stelmachowski, P.; Monteverde Videla, A. H. A.; Jakubek, T.; Kotarba, A.; Specchia, S. The Effect of Fe, Co, and Ni Structural Promotion of Cryptomelane $\left(\mathrm{KMn}_{8} \mathrm{O}_{16}\right)$ on the Catalytic Activity in Oxygen Evolution Reaction. Electrocatalysis 2018, 9, 762-769.

(14) Li, Y.; Fan, Z.; Shi, J.; Liu, Z.; Zhou, J.; Shangguan, W. Modified Manganese Oxide Octahedral Molecular Sieves M'-OMS-2 $\left(\mathrm{M}^{\prime}=\mathrm{Co}, \mathrm{Ce}, \mathrm{Cu}\right)$ as Catalysts in Post Plasma-Catalysis for Acetaldehyde Degradation. Catal. Today 2015, 256, 178-185.

(15) Hernández, W. Y.; Centeno, M. A.; Ivanova, S.; Eloy, P.; Gaigneaux, E. M.; Odriozola, J. A. Cu-Modified Cryptomelane Oxide as Active Catalyst for CO Oxidation Reactions. Appl. Catal., B 2012, 123-124, 27-35.

(16) Kumar, R.; Mittal, J.; Kushwaha, N.; Rao, B. V.; Pandey, S.; Liu, C.-P. Room Temperature Carbon Monoxide Gas Sensor Using $\mathrm{Cu}$ Doped OMS-2 Nanofibers. Sens. Actuators, B 2018, 266, 751-760.

(17) Dey, S.; Dhal, G. C. A Review of Synthesis, Structure and Applications in Hopcalite Catalysts for Carbon Monoxide Oxidation. Aerosol Sci. Eng. 2019, 3, 97-131.

(18) Konsolakis, M. The Role of Copper-Ceria Interactions in Catalysis Science: Recent Theoretical and Experimental Advances. Appl. Catal., B 2016, 198, 49-66.

(19) Beckers, J.; Rothenberg, G. Sustainable Selective Oxidations Using Ceria-Based Materials. Green Chem. 2010, 12, 939-948.

(20) Kašpar, J.; Di Monte, R.; Fornasiero, P.; Graziani, M.; Bradshaw, H.; Norman, C. Dependency of the Oxygen Storage Capacity in Zirconia-Ceria Solid Solutions upon Textural Properties. Top. Catal. 2001, 16, 83-87.

(21) Rico-Pérez, V.; Bueno-López, A. Effect of $\mathrm{RhO}_{\mathrm{x}} / \mathrm{CeO}_{2}$ Calcination on Metal-Support Interaction and Catalytic Activity for $\mathrm{N}_{2} \mathrm{O}$ Decomposition. Appl. Sci. 2014, 4, 468-481.

(22) DeGuzman, R. N.; Shen, Y.-F.; Neth, E. J.; Suib, S. L.; O’Young, C.-L.; Levine, S.; Newsam, J. M. Synthesis and Characterization of Octahedral Molecular Sieves (OMS-2) Having the Hollandite Structure. Chem. Mater. 1994, 6, 815-821.

(23) Atribak, I.; Bueno-López, a.; García-García, a.; Navarro, P.; Frías, D.; Montes, M. Catalytic Activity for Soot Combustion of Birnessite and Cryptomelane. Appl. Catal., B 2010, 93, 267-273.

(24) Lee, H. C.; Kim, D. H. Kinetics of $\mathrm{CO}$ and $\mathrm{H}_{2}$ Oxidation over CuO- $-\mathrm{CeO}_{2}$ Catalyst in $\mathrm{H}_{2}$ Mixtures with $\mathrm{CO}_{2}$ and $\mathrm{H}_{2} \mathrm{O}$. Catal. Today 2008, 132, 109-116.

(25) Gamarra, D.; Martínez-Arias, A. Preferential Oxidation of CO in Rich $\mathrm{H}_{2}$ over $\mathrm{CuO} / \mathrm{CeO}_{2}$ : Operando-DRIFTS Analysis of Deactivating Effect of $\mathrm{CO}_{2}$ and $\mathrm{H}_{2} \mathrm{O}$. J. Catal. 2009, 263, 189-195.

(26) Njagi, E. C.; Genuino, H. C.; King'ondu, C. K.; Chen, C.-H.; Horvath, D.; Suib, S. L. Preferential Oxidation of $\mathrm{CO}$ in $\mathrm{H}_{2}$-Rich Feeds over Mesoporous Copper Manganese Oxides Synthesized by a Redox Method. Int. J. Hydrogen Energy 2011, 36, 6768-6779.

(27) Davó-Quiñonero, A.; Lozano-Castelló, D.; Bueno-López, A. Unexpected Stability of $\mathrm{CuO} /$ Cryptomelane Catalyst under Preferential Oxidation of $\mathrm{CO}$ Reaction Conditions in the Presence of $\mathrm{CO}_{2}$ and $\mathrm{H}_{2} \mathrm{O}$. Appl. Catal., $B$ 2017, 217, 459-465.

(28) Ho, P. H.; Lee, S. C.; Kim, J.; Lee, D.; Woo, H. C. Properties of a Manganese Oxide Octahedral Molecular Sieve (OMS-2) for Adsorptive Desulfurization of Fuel Gas for Fuel Cell Applications. Fuel Process. Technol. 2015, 131, 238-246.

(29) Davó-Quiñonero, A.; Navlani-García, M.; Lozano-Castelló, D.; Bueno-López, A. $\mathrm{CuO} /$ Cryptomelane Catalyst for Preferential Oxidation of $\mathrm{CO}$ in the Presence of $\mathrm{H}_{2}$ : Deactivation and Regeneration. Catal. Sci. Technol. 2016, 6, 5684-5692.

(30) Stelmachowski, P.; Legutko, P.; Jakubek, T.; Indyka, P.; Sojka, Z.; Holmlid, L.; Kotarba, A. Emission of Highly Excited Electronic States of Potassium from Cryptomelane Nanorods. Phys. Chem. Chem. Phys. 2015, 17, 26289-26294.

(31) Davó-Quiñonero, A.; Such-Basáñez, I.; Juan-Juan, J.; LozanoCastelló, D.; Stelmachowski, P.; Grzybek, G.; Kotarba, A.; BuenoLópez, A. New Insights into the Role of Active Copper Species in 
$\mathrm{CuO} /$ Cryptomelane Catalysts for the CO-PROX Reaction. Appl. Catal., B 2020, 267, 118372-118383.

(32) Ho, P. H.; Lee, S. C.; Kim, J.; Lee, D.; Woo, H. C. Properties of a Manganese Oxide Octahedral Molecular Sieve (OMS-2) for Adsorptive Desulfurization of Fuel Gas for Fuel Cell Applications. Fuel Process. Technol. 2015, 131, 238-246.

(33) Yu, D.; Ren, Y.; Yu, X.; Fan, X.; Wang, L.; Wang, R.; Zhao, Z.; Cheng, K.; Chen, Y.; Sojka, Z.; Kotarba, A.; Wei, Y.; Liu, J. Facile Synthesis of Birnessite-Type $\mathrm{K}_{2} \mathrm{Mn}_{4} \mathrm{O}_{8}$ and Cryptomelane-Type $\mathrm{K}_{2-\mathrm{X}} \mathrm{Mn}_{8} \mathrm{O}_{16}$ Catalysts and Their Excellent Catalytic Performance for Soot Combustion with High Resistance to $\mathrm{H}_{2} \mathrm{O}$ and $\mathrm{SO}_{2}$. Appl. Catal., B 2021, 285, 119779-119793.

(34) Vepřek, S.; Cocke, D. L.; Kehl, S.; Oswald, H. R. Mechanism of the Deactivation of Hopcalite Catalysts Studied by XPS, ISS, and Other Techniques. J. Catal. 1986, 100, 250-263.

(35) Mirzaei, A. A.; Shaterian, H. R.; Kaykhaii, M. The X-Ray Photoelectron Spectroscopy of Surface Composition of Aged Mixed Copper Manganese Oxide Catalysts. Appl. Surf. Sci. 2005, 239, 246254.

(36) Dey, S.; Dhal, G. C. Deactivation and Regeneration of Hopcalite Catalyst for Carbon Monoxide Oxidation: A Review. Mater. Today Chem. 2019, 14, 100180-100194.

(37) Caputo, T.; Lisi, L.; Pirone, R.; Russo, G. On the Role of Redox Properties of $\mathrm{CuO} / \mathrm{CeO}_{2}$ Catalysts in the Preferential Oxidation of $\mathrm{CO}$ in $\mathrm{H}_{2}$-Rich Gases. Appl. Catal., A 2008, 348, 42-53.

(38) Giménez-Mañogil, J.; Bueno-López, A.; García-García, A. Preparation, Characterisation and Testing of $\mathrm{CuO} / \mathrm{Ce}_{0.8} \mathrm{Zr}_{0.2} \mathrm{O}_{2}$ Catalysts for $\mathrm{NO}$ Oxidation to $\mathrm{NO}_{2}$ and Mild Temperature Diesel Soot Combustion. Appl. Catal., B 2014, 152-153, 99-107.

(39) Davó-Quiñonero, A.; Bailón-García, E.; López-Rodríguez, S.; Juan-Juan, J.; Lozano-Castelló, D.; García-Melchor, M.; Herrera, F. C.; Pellegrin, E.; Escudero, C.; Bueno-López, A. Insights into the Oxygen Vacancy Filling Mechanism in $\mathrm{CuO} / \mathrm{CeO}_{2}$ Catalysts: A Key Step Toward High Selectivity in Preferential CO Oxidation. ACS Catal. 2020, 10, 6532-6545.

(40) Polster, C. S.; Nair, H.; Baertsch, C. D. Study of Active Sites and Mechanism Responsible for Highly Selective CO Oxidation in $\mathrm{H}_{2}$ Rich Atmospheres on a Mixed $\mathrm{Cu}$ and $\mathrm{Ce}$ Oxide Catalyst. J. Catal. 2009, 266, 308-319.

(41) Sedmak, G.; Hočevar, S.; Levec, J. Kinetics of Selective CO Oxidation in Excess of $\mathrm{H}_{2}$ over the Nanostructured $\mathrm{Cu}_{0.1} \mathrm{Ce}_{0.9} \mathrm{O}_{2-\mathrm{y}}$ Catalyst. J. Catal. 2003, 213, 135-150.

(42) Lykaki, M.; Pachatouridou, E.; Carabineiro, S. A. C.; Iliopoulou, E.; Andriopoulou, C.; Kallithrakas-Kontos, N.; Boghosian, S.; Konsolakis, M. Ceria Nanoparticles Shape Effects on the Structural Defects and Surface Chemistry: Implications in CO Oxidation by $\mathrm{Cu} / \mathrm{CeO}_{2}$ Catalysts. Appl. Catal., B 2018, 230, 18-28. 